\title{
Application of Coulometric Titration for the Certification of Primary Reference Materials of Pure Substances
}

\author{
Gennady I. Terentiev, Alena V. Sobina, Alexandr J. Shimolin, Veniamin M. Zyskin \\ Ural Scientific and Research Institute for Metrology, Ekaterinburg, Russia \\ Email: terentiev@uniim.ru
}

Received 15 April 2014; revised 30 May 2014; accepted 13 June 2014

Copyright (C) 2014 by authors and Scientific Research Publishing Inc.

This work is licensed under the Creative Commons Attribution International License (CC BY). http://creativecommons.org/licenses/by/4.0/

(c) (i) Open Access

\begin{abstract}
In this article, the block scheme and metrological characteristics of the State primary standard of the mass (molar) fraction and mass (molar) concentration of the component in the liquid and solid substances and materials based on coulometric titration GET 176-2010 are given. Primary reference materials certified by coulometric titration in the Ural Scientific and Research Institute for Metrology include eight certified reference materials (CRMs) of pure solid substances (mostly salts of sodium or potassium) and one hydrochloric acid solution CRM. The metrological characteristics of these reference materials and the scheme of their application in titrimetric analysis are shown. The expanded uncertainty of the certified value (mass fraction for the solid substances or molar concentration for the solution) is in the range from $0.018 \%$ to $0.05 \%$. Information about two primary reference materials of high purity iron and lead nitrate certified by controlled-potential coulometry with expanded uncertainty from $0.04 \%$ to $0.07 \%$ is also given.
\end{abstract}

\section{Keywords}

Coulometric Titration, Controlled-Potential Coulometry, Primary Reference Materials, High Purity Substances, State Primary Standard

\section{Introduction}

Coulometric measurement methods used to elucidate chemical composition of substances occupy an important place in analytical chemistry due to a number of advantages, the most significant of which is the possibility to carry out measurements of amount content of components with high accuracy without using reference materials. The Consultative Committee for Amount of Substance-Metrology in Chemistry (CCQM) of the International 
Bureau of Weights and Measures (BIPM) has included coulometry as a method which has potential to be considered a primary one [1].

Coulometric methods are based on the Faraday laws stating that 1) the mass of a substance altered at an electrode during electrolysis is directly proportional to the quantity of electricity transferred at that electrode and 2) the amounts of chemical changes produced by the same quantity of electricity transferred in different substances are proportional to their equivalent weights.

In the case of coulometric titration, an electrochemical reaction proceeds at a controlled constant current in the corresponding electrolyte, the product of electrochemical reaction acts as a titrant and stoichiometrically interacts with the analyzed component. A titration end point is determined usually by an instrumental method (potentiometric, amperometric, photometric). A necessary condition for using the definite electrochemical reaction during coulometric titration is that the current efficiency must be $100 \%$, i.e., the measured quantity of electricity must only be utilized for altering one certain substance.

The main features of coulometric titration are high accuracy, the ability to conduct measurements without reference to a standard of the measurand (i.e., without certified reference materials with known content of ananalyte), the possibility of using unstable reagents and ease of automation. The disadvantage of coulometric titration is lower selectivity coupled with it being a titrimetric technique.

Since the second half of $\mathrm{XX}^{\text {th }}$ century, coulometric titration has been applied for certification of primary reference materials of pure chemical substances to be used as standards for other relative methods of quantitative chemical analysis, in particular, for titrimetry. These primary reference materials provide a straight traceability chain to the SI units. National standards and the high-precision systems based on the method of coulometric titration are operated in the USA, Germany, Slovakia, Japan, South Korea, China, Russia [2] and other countries.

\section{Method Implementation}

During the period 1976-1981, the Ural Scientific and Research Institute for Metrology (FGUP "UNIIM") created and certified a "High-accuracy installation (UVT) for reproducing the unit of the base substance mass fraction in certified reference materials of chemical substances by coulometric titration: UVT 14-A-81". In 2008-2010,UVT 14-A-81 was completely updated and investigated, the complex of new apparatuses was approved as the "State primary standard of units of the mass (molar) fraction and mass (molar) concentration of a component in liquid and solid substances and materials based on coulometric titration GET 176-2010". An external view and the block scheme of GET 176 are presented in Figure 1 and Figure 2. The principle of operation of GET 176 lies in the following: a constant current from the highly-stable current source (2) is applied to the generating electrodes of the coulometric cell (4) through the resistance coil (3) immersed in an oil bath (6) at constant temperature. Values of generation time and current are set on the current source (2) using a dedicated computer program. An exact current value is calculated by measuring the voltage drop on the resistance coil (3) by means of digital nanovoltmeter (1). Depending on type of reaction in the cell, the end point of titration is determined by the indicating system (5) which is based on a high-precision $\mathrm{pH}(\mathrm{pX})$-meter or picoammeter and electrodes. Sample mass is measured by weighing with appropriate buoyancy correction by means of a high precision electronic microbalance (7).

The home-made GET 176 coulometric cell has a number design features in comparison to the UVT 14-A-81 cell such as: a smaller size(using the lesser volume in working chamber increases sensitivity of the indicating system for the end point determination); the possibility of using argon purging in all three cell chambers (working, intermediate and auxiliary) for effective removal of interfering gases, for example carbon dioxide for acid-base titrations; the possibility of slow ejection of the electrolyte from the intermediate chamber into the working one during the main titration for reducing ion migration into the auxiliary chamber; a shield preventing spray losses of sample or titrant during the argon purging;- - a home-made frit-ended bubbler for purging the electrolyte in working chamber for faster and more effective removal of interfering gases. The rate of argon flow is controlled by a rotameter. A schematic of the cell is shown in Figure 3.

The measurement equation for the mass fraction of the component of interest is defined as

$$
A=\frac{100 M\left(U_{1} \cdot\left(t_{1}^{\prime}-t_{1}\right)+U_{2} \cdot t_{2}+U_{3} \cdot t_{3}\right)}{z \cdot F \cdot m \cdot R},
$$

where: $A$ is the mass fraction of the analyte in the analyzed sample,\%;

$U_{1}$ is an average value of voltage during the preliminary titration, $\mathrm{V}$; 


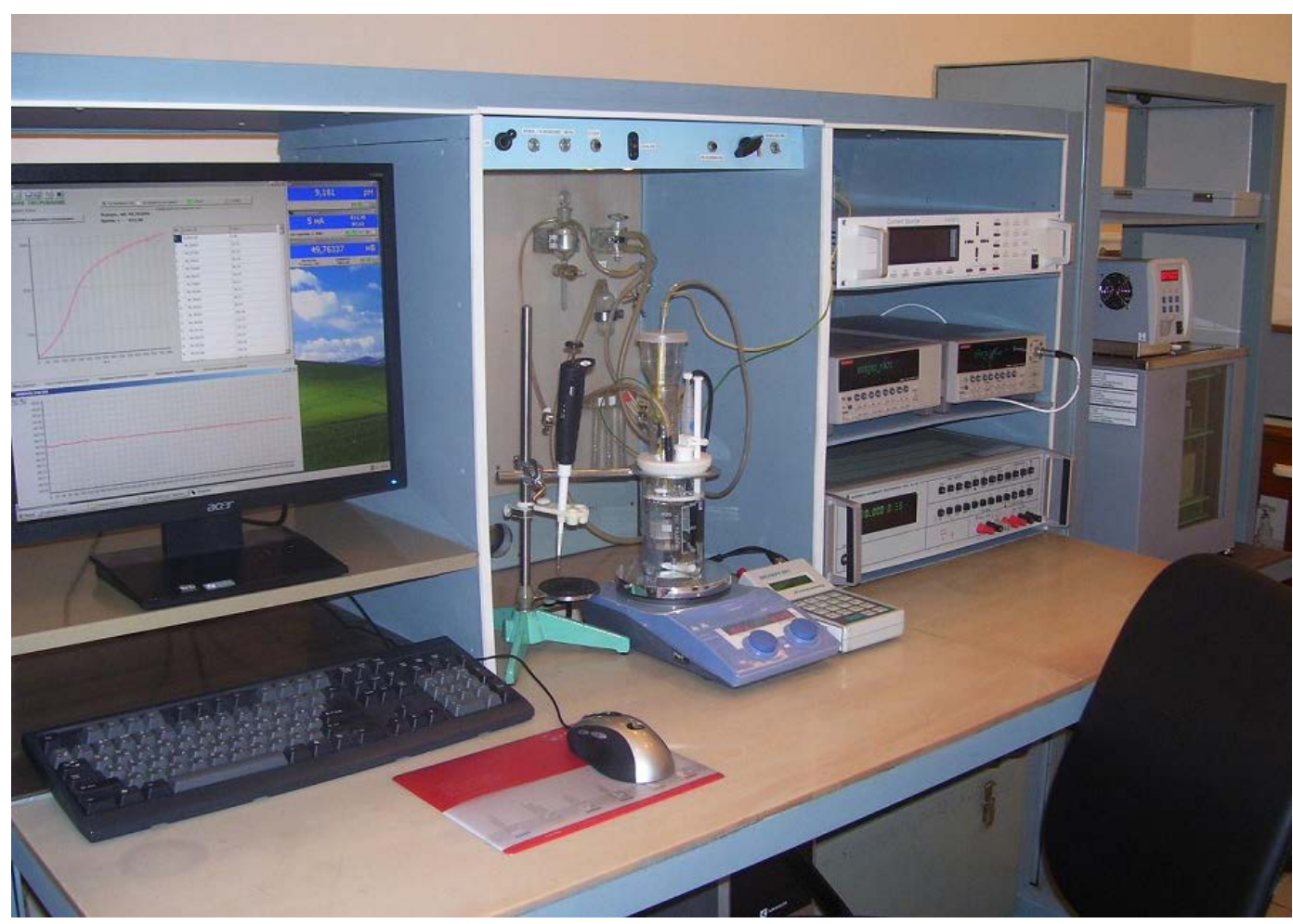

Figure 1. An external view of the "State primary standard of the units of mass (molar) fraction and mass (molar) concentration of the component in liquid and solid substances and materials based on coulometric titration method GET 176-2010”.

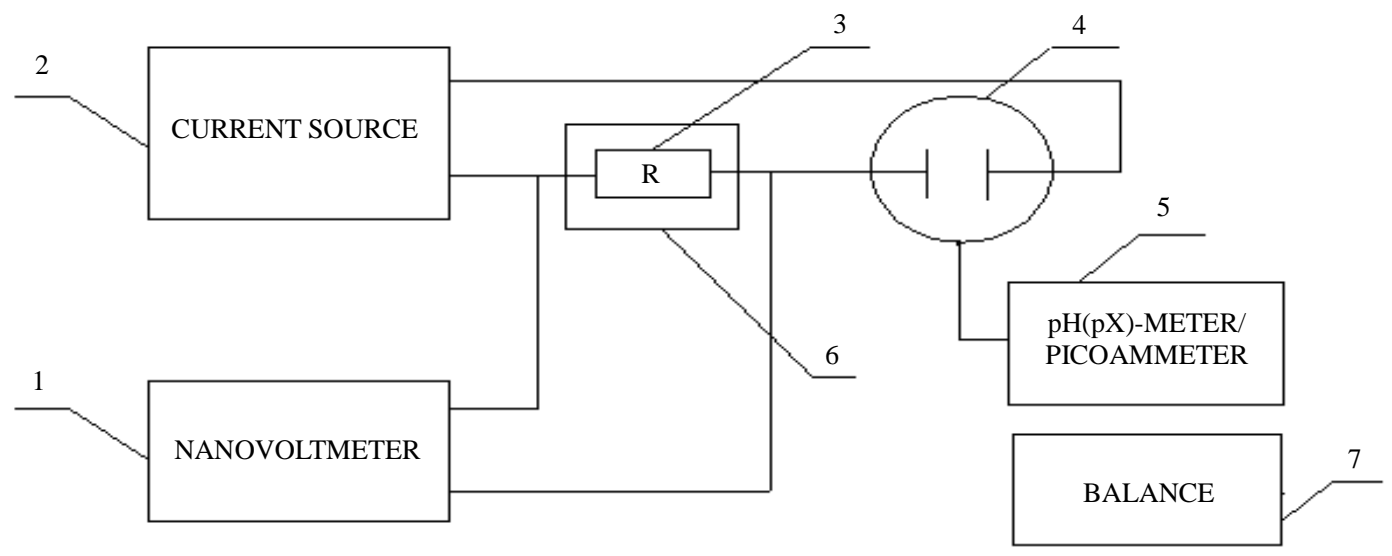

Figure 2. Schematic of the State standard of the units of mass (molar) fraction and mass (molar) concentration of the component in liquid and solid substances and materials based of coulometric titration method GET 176-2010. 1. digital voltmeter (for the range $100 \mathrm{mV}$ accuracy is $\pm(30 \mathrm{a}+4 \mathrm{~b})$, for the range $10 \mathrm{~V}$ accuracy is $\pm(25 a+2 b)$, where a is ppm of readings and b is ppm of range); 2 . high-stability programmable current source with a time-counter (the maximum output voltage is $100 \mathrm{~V}$, the maximum output current $0.5 \mathrm{~A}$, current accuracy $\left(2 \times 10^{-5} \cdot \mathrm{I}+2 \times 10^{-6}\right) \mathrm{A}$, time accuracy is $\left.\left(1 \times 10^{-6} \cdot \mathrm{T}+5 \times 10^{-4}\right) \mathrm{s}\right)$; 3 . resistance coil (nominal resistance value is $10 \mathrm{Ohm}$, accuracy is $\pm 0.0005 \%$ ); 4 . coulometric cell; 5 . complex of measuring apparatuses for the determination of titration end point: for potentiometric indication a $\mathrm{pH}(\mathrm{pX})$ meter (accuracy $\pm 0.2 \mathrm{mV} ; \pm 0.03 \mathrm{pX}(\mathrm{pH}), \pm 0.5^{\circ} \mathrm{C}$ ) with the glass combined electrode or corresponding ion-selective electrode and a reference electrode is used; for amperometric indication a picoammeter (accuracy for the range from $0.1 \mu \mathrm{A}$ to $20 \mathrm{~mA}$ is from $\pm 2.0 \times 10^{-6} \mathrm{nA}$ to $\pm 8.0 \times 10^{-1} \mathrm{nA}$ ) and a voltage source/voltmeter (for the range of voltage supplying $10 \mathrm{~V}$ accuracy is $\pm\left(2 U+0.7 U_{n}\right) \times 10^{-6} \mathrm{~V}$, where $U$ is instrument readings, $\mathrm{V}, U_{n}$ is a measurement range, V) and home-made indicating electrodes are used; 6. high precision electronic balance (weighing capacity is $5.1 \mathrm{~g}$, and accuracy is $\pm 20 \mu \mathrm{g}$ ). 


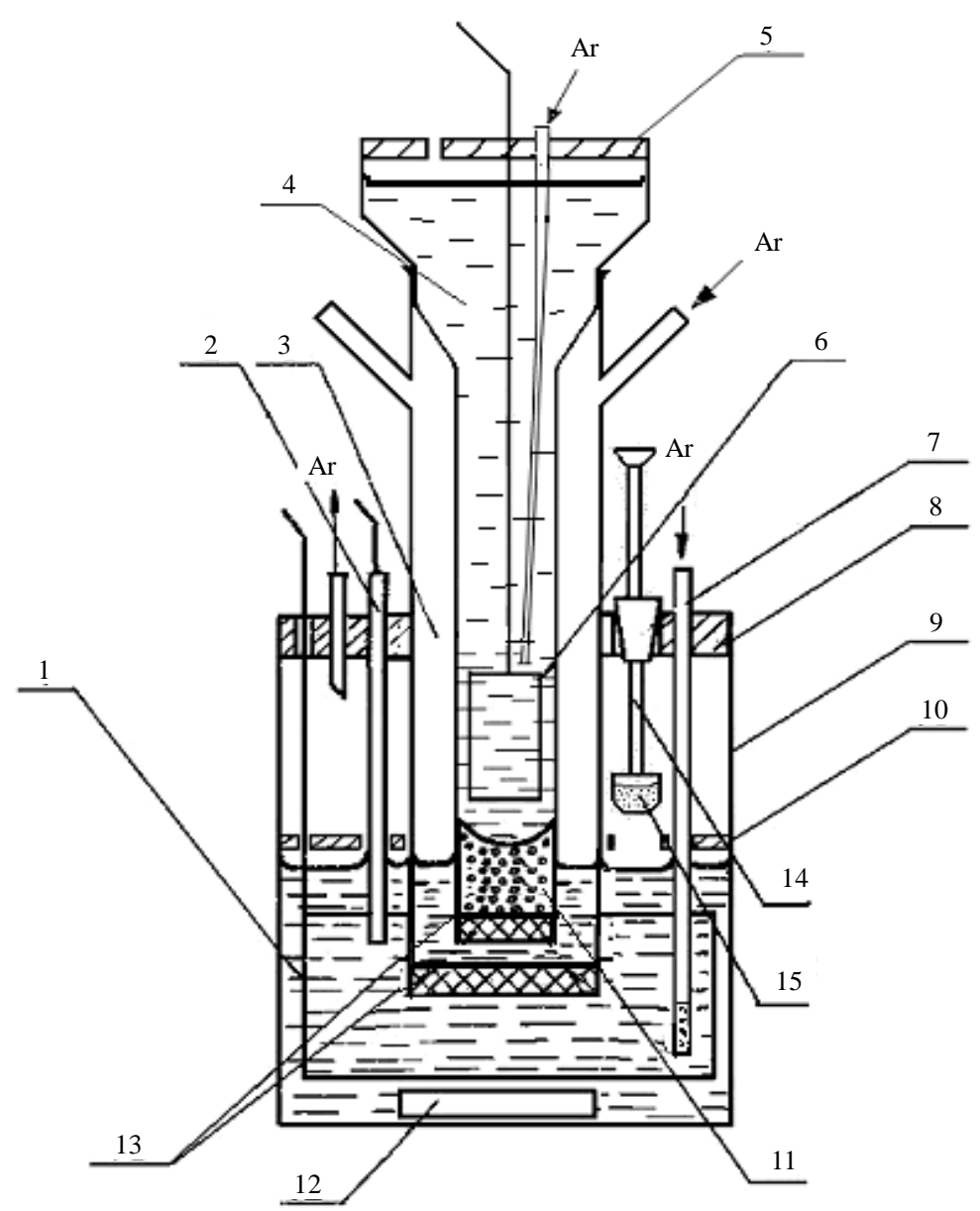

Figure 3. Schematic of the GET 176 coulometric cell. 1. generating electrode; 2. indicating electrode (electrodes); 3. intermediate chamber; 4. auxiliary chamber; 5 . cover for the auxiliary chamber; 6 . auxiliary electrode; 7 . bubbler; 8 . cover for the working chamber; 9 . working chamber; 10 . mobile spray shield; 11 . gel plug; 12 . magnetic stirrer; 13 . porous frit; 14 . mechanism for sample input; 15 . cup with the sample.

$U_{2}$ is an average value of voltage during the main titration, $\mathrm{V}$;

$U_{3}$ is an average value of voltage during the final titration, $\mathrm{V}$;

$t_{1}^{\prime}$ is a time of preliminary titration, $\mathrm{s}$;

$t_{1}$ is a time corresponding to the end point of the preliminary titration, s;

$t_{2}$ is the time for the main titration, $\mathrm{s}$;

$t_{3}$ is a time corresponding to the end point of final titration, s;

$M$ is molar mass of the analyzed substance, $\mathrm{g} / \mathrm{mol}$;

$Z$ is a number of electrons taking part in the electrochemical reaction;

$F$ is Faraday constant, $\mathrm{C} / \mathrm{mol}$;

$m$ is a sample mass, $\mathrm{g}$;

$R$ is a resistance of the thermostated coil, $\Omega$.

For uncertainty calculations, the recommendations of the GUM [3] were used. Type A relative standard uncertainty is estimated as a standard deviation of the mean for seven determinations. Type B relative standard uncertainty is evaluated as a combination of the contributions arising from the input quantities in Equation (1) and chemical sources such as the influence of carbon dioxide for acid-base titrations and oxygen for Red-Ox titrations, diffusion of the analyte ions to the intermediate and auxiliary cell chambers, electrolyte impurities, and the influence of environment conditions. 


\section{Results and Discussion}

The metrological characteristics of the State primary standard based on coulometric titration method GET 176-2010 are given in Table 1.

Calibration and measurment capabilities (CMC) of the developed State standard based on coulometric titration method GET 176-2010 and its equivalence to foreign analogues are confirmed by results from a number of international key and pilot comparisons [4]-[6]. UNIIM has CMCs for the measurement of the mass fraction of the main component in pure chemical substances on the web database of the BIPM [7].

The list of primary reference materials certified by coulometric titration and their metrological characteristics are given in the Table 2. The list includes 8 CRMs of pure solid substances and one CRM of a hydrochloric acid solution. All solid substances are characterized by their ease of acquisition in a high degree of purity, high temporal stability and interacting stoichiometrically with a titrant. Six types of certified reference materials of high purity substances were developed on the basis of UVT 14-A-81 in 1981-1987s and later repeated batches were issued.

Table 1. Metrological characteristics of the "State primary standard of the units of mass (molar) fraction and mass (molar) concentration of the component in liquid and solid substances and materials based on coulometric titration method GET 176-2010”.

\begin{tabular}{|c|c|c|c|c|}
\hline \multirow[b]{2}{*}{ Characteristic } & \multicolumn{4}{|c|}{ Value of characteristic } \\
\hline & $\begin{array}{l}\text { Mass fraction of } \\
\text { the component }\end{array}$ & $\begin{array}{l}\text { Molar fraction of } \\
\text { the component }\end{array}$ & $\begin{array}{l}\text { Mass concentration of } \\
\text { the component }\end{array}$ & $\begin{array}{l}\text { Molar concentration of } \\
\text { the component }\end{array}$ \\
\hline Measurement range & $\begin{array}{l}\text { From } 99.000 \% \\
\text { to } 100.000 \%\end{array}$ & $\begin{array}{l}\text { From } 99.000 \% \\
\text { to } 100.000 \%\end{array}$ & From 5 to $100 \mathrm{~g} / \mathrm{dm}^{3}$ & From 0.1 to $2 \mathrm{~mole} / \mathrm{dm}^{3}$ \\
\hline $\begin{array}{l}\text { Type A relative standard uncertainty, } \\
u_{o A} \text { (for } 7 \text { independent determinations), \% }\end{array}$ & $0.002-0.003$ & $0.002-0.003$ & $0.007-0.009$ & $0.007-0.009$ \\
\hline Type B relative standard uncertainty, $u_{o B}, \%$ & 0.005 & 0.005 & 0.009 & 0.009 \\
\hline
\end{tabular}

Table 2. Primary reference materials certified by the method of coulometric titration.

\begin{tabular}{|c|c|c|c|c|c|}
\hline $\begin{array}{l}\text { Name of the } \\
\text { primary CRM }\end{array}$ & $\begin{array}{l}\text { CRM and } \\
\text { batch No. }\end{array}$ & $\begin{array}{l}\text { Certified } \\
\text { characteristic }\end{array}$ & $\begin{array}{c}\text { Certified } \\
\text { value range }\end{array}$ & $\begin{array}{l}\text { Expanded uncertainty } \\
\text { of the certified value } \\
(\mathrm{P}=0.95), \%\end{array}$ & $\begin{array}{l}\text { Area of application } \\
\text { in titrimetry }\end{array}$ \\
\hline $\begin{array}{l}\text { CRM for composition } \\
\text { of potassium hydrogen } \\
\text { phthalate }\end{array}$ & $\begin{array}{l}\text { GSO 2216-81 } \\
\text { (batch 14, 2012) }\end{array}$ & $\begin{array}{l}\text { Mass fraction of } \\
\text { potassium } \\
\text { hydrogen phthalate }\end{array}$ & $99.90-100.00$ & 0.018 & Acidimetry \\
\hline $\begin{array}{l}\text { CRM for composition } \\
\text { of sodium carbonate }\end{array}$ & $\begin{array}{l}\text { GSO 4086-87 } \\
\text { (batch 2, 2014) }\end{array}$ & $\begin{array}{l}\text { Mass fraction of } \\
\text { sodium carbonate }\end{array}$ & $99.95-100.00$ & 0.028 & Alkalimetry \\
\hline $\begin{array}{l}\text { CRM for composition } \\
\text { of potassium dichromate }\end{array}$ & $\begin{array}{l}\text { GSO 2215-81 } \\
\text { (batch 16, 2011) }\end{array}$ & $\begin{array}{l}\text { Mass fraction of } \\
\text { potassium } \\
\text { dichromate }\end{array}$ & 99.95 - 100.00 & 0.018 & Oxidimetry \\
\hline $\begin{array}{l}\text { CRM for composition } \\
\text { of sodium oxalate }\end{array}$ & $\begin{array}{l}\text { GSO 3219-85 } \\
\text { (batch 7, 2001) }\end{array}$ & $\begin{array}{l}\text { Mass fraction of } \\
\text { sodium oxalate }\end{array}$ & $99.95-100.00$ & 0.03 & Reductometry \\
\hline $\begin{array}{l}\text { CRM for composition } \\
\text { of trilon B (disodium salt } \\
\text { of ethylene- } \\
\text { diamintetraacetic acid) }\end{array}$ & $\begin{array}{l}\text { GSO 2960-84 } \\
\text { (batch 11, 2009) }\end{array}$ & $\begin{array}{l}\text { Mass fraction of } \\
\text { trilon B (disodium } \\
\text { salt of ethylendiamin- } \\
\text { tetraacetic acid) }\end{array}$ & $99.70-100.00$ & 0.03 & Complexonometry \\
\hline $\begin{array}{l}\text { CRM for composition } \\
\text { of sodium chloride }\end{array}$ & $\begin{array}{l}\text { GSO 4391-88 } \\
\text { (batch 3, 2012) }\end{array}$ & $\begin{array}{l}\text { Mass fraction of } \\
\text { sodium chloride }\end{array}$ & $99.90-100.00$ & 0.024 & Sedimentometry \\
\hline $\begin{array}{l}\text { CRM for composition } \\
\text { of ethylene- } \\
\text { diamintetraacetic acid }\end{array}$ & $\begin{array}{l}\text { GSO } 9655-2010 \\
\text { (batch } 1,2010 \text { ) }\end{array}$ & $\begin{array}{l}\text { Mass fraction of } \\
\text { ethylendiamin- } \\
\text { tetraacetic acid }\end{array}$ & $99.70-100.00$ & 0.05 & Complexonometry \\
\hline $\begin{array}{l}\text { CRM for composition } \\
\text { of hydrochloric acid } \\
\text { solution }\end{array}$ & $\begin{array}{l}\text { GSO 9654-2010 } \\
\text { (batch 2, 2013) }\end{array}$ & $\begin{array}{l}\text { Molar concentration of } \\
\text { hydrogen ions, } \\
\text { mole/dm }{ }^{3}\end{array}$ & $0.099-0.110$ & 0.037 & Acidimetry \\
\hline $\begin{array}{l}\text { CRM for composition } \\
\text { of potassium chloride }\end{array}$ & $\begin{array}{l}\text { GSO 9969-2011 } \\
\text { (batch 1, 2012) }\end{array}$ & $\begin{array}{l}\text { Mass fraction of } \\
\text { potassium chloride }\end{array}$ & $99.90-100.00$ & 0.024 & Sedimentometry \\
\hline
\end{tabular}


Since 2010, three new types of primary reference materials have been developed at UNIIM using the State primary standard based on coulometric titration. They include CRM of ethylendiamintetraacetic acid (EDTA), potassium chloride and hydrochloric acid solution. Purity of reactants used as materials for the CRMs was investigated using various physical and chemical methods, including mass spectrometry, IR-Fourier spectroscopy, thermogravimetry, differential scanning calorimetry and capillary electrophoresis. Inductively-coupled plasma mass spectrometry was used for the monitoring of element impurities in the developed CRMs of pure chemical substances. Quadropole mass spectrometry was used to ensure the absence of volatile impurity components. The method of capillary electrophoresis was applied for monitoring cationic and anionic impurities in CRM potassium chloride. Methods of thermogravimetry and differential scanning calorimetry were used for specification of hygroscopic moisture removal conditions (temperature and time of drying) of EDTA. IR-Fourier spectroscopy was used to ensure the absence of organic impurity components in ethylendiamintetraacetic acid. The results generated by various methods confirmed the high purity of a chemical compound of reagents used for development of the CRMs.

Investigating homogeneity and measurements to establish the certified value of the CRMs were executed using the primary method of coulometric titration using GET 176. The homogeneity of solid substance CRMs (EDTA and KCl) was estimated by the method of ANOVA according to [8]. Homogeneity of the hydrochloric acid solution CRM was not investigated as the material is a true solution. Stability of the developed CRMs was based on the principles of spontaneous and isochronous ageing.

The primary CRMs of pure chemical substances and their solutions are used as facilities of storage and transferring units reproduced by GET 176. These CRMs cover all types of chemical reactions implemented in titrimetry: the acid-base reactions (potassium hydrogen phthalate, sodium carbonate, hydrochloric acid solution), oxidation-reduction ones (potassium dichromate, sodium oxalate), complexation reactions (trilon B, EDTA) and sedimentation reactions (sodium chloride, potassium chloride). The scheme of application of the primary CRMs certified by the method of coulometric titration in titrimetry is shown in Figure 4. According to this scheme the concentration of a titrant is determined using corresponding primary CRM by direct measurement or via comparison solution.

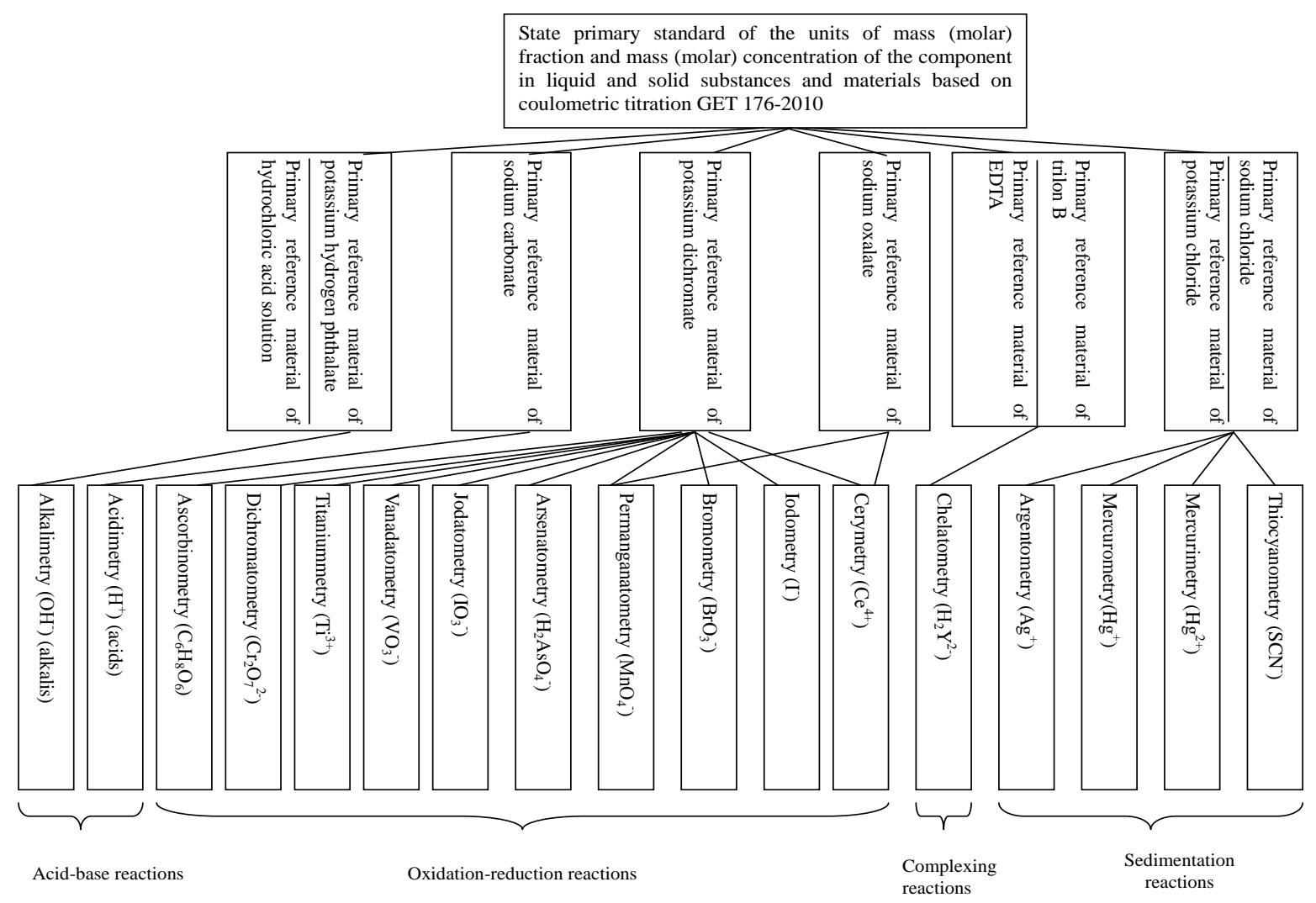

Figure 4. Scheme of application of the primary reference materials of pure substances in titrimetry. 
Table 3. Primary reference materials certified by the method of controlled-potential coulometry.

\begin{tabular}{|c|c|c|c|c|}
\hline Name of the primary CRM & CRM no. & Certified characteristic & Certified value & $\begin{array}{l}\text { Expanded uncertainty of the } \\
\text { certified value }(P=0.95), \%\end{array}$ \\
\hline $\begin{array}{l}\text { CRM for composition of } \\
\text { high purity iron }\end{array}$ & $\begin{array}{l}\text { GSO 9497-2009 } \\
\text { (batch 1, 2010) }\end{array}$ & Mass fraction of iron & $99.80-100.00$ & 0.04 \\
\hline \multirow{2}{*}{$\begin{array}{l}\text { CRM for composition of } \\
\text { lead nitrate }\end{array}$} & \multirow{2}{*}{$\begin{array}{l}\text { GSO 10275-2013 } \\
\text { (batch 1, 2013) }\end{array}$} & Mass fraction of lead & $62.30-62.56$ & 0.07 \\
\hline & & Mass fraction of lead nitrate & $99.60-100.00$ & 0.07 \\
\hline
\end{tabular}

The order of application of the primary reference materials of pure substances certified by coulometric titration is regulated by the national standard GOST R 8.600-2003 "State system of insuring the uniformity of measurements. Measurement procedures for the base substance mass fraction of reactants and superpure substances by titrimetric methods. General requirements" [8]. The corresponding measurement procedures are documented.

The primary reference materials of pure substances certified by coulometric titration are widely applied in the practice of analytical measurements for several purposes:

- To determine the concentration of the titrated solution with known uncertainty; in this case, the accuracy of quantitative chemical analysis is the highest;

- To establish the certified value of other CRMs;

- To exercise within-laboratory or external control of the accuracy of quantitative analysis measurement results;

- For validating measurement procedures, etc.

In 2012-2013, GET 176 was augmented by the addition of a high-precision system implementing a method of controlled-potential coulometry which allows measurement of the content of components in pure metals, metal oxides and alloys in wider range (from $1 \%$ to $100 \%$ as mass fraction) with expanded uncertainty from $0.012 \%$ to $0.20 \%$. Two new types of primary CRMs of pure chemical substances were created using this system based on a controlled-potential coulometry method. The metrological characteristics of the CRMs are shown in Table 3.

\section{Conclusion}

Primary reference materials of pure chemical substances and their solutions certified by the primary methods of coulometric titration or controlled-potential coulometry are traceable to the SI units and by means of the continuous chain of comparisons using validated measurement procedures to provide traceability both to reference materials of lower categories and routine measurement results in ecology and public health services, nuclear, pharmaceutical, the food-processing industries, black and nonferrous metallurgy and other branches of chemistry and commerce.

\section{References}

[1] Milton, M.J.T. and Quinn, T.J. (2001) Primary Methods for the Measurement of Amount of Substance. Metrologia, 38, 289-296. http://dx.doi.org/10.1088/0026-1394/38/4/1

[2] Mariassy, M., Pratt, K.W. and Spitzer, P. (2009) Major Applications of Electrochemical Techniques at National Metrology Institutes. Metrologia, 46, 199-213. http://dx.doi.org/10.1088/0026-1394/46/3/007

[3] JCGM 100:2008 Evaluation of Measurement Data—Guide to the Expression of Uncertainty in Measurement. http://www.bipm.org/utils/common/documents/jcgm/JCGM 1002008 E.pdf

[4] Key Comparison CCQM-K34.2. Assay of Potassium Hydrogen Phthalate. Final Report. http://kcdb.bipm.org/appendixB/appbresults/ccqm-k34/ccqm-k34.2_final_report.pdf

[5] Borges, P.P., Silva Junior, W.B., Gonzaga, F.B., Sobina, A., Shimolin, A. and Terentiev, G. (2012) Coulometric Determination of Amount Content of Potassium Dichromate for Comparability Assessment through a Bilateral Comparison. XX IMEKO World Congress Metrology for Green Growth: Book of Abstracts. Busan. http://www.imeko.org/publications/wc-2012/IMEKO-WC-2012-TC24-P3.pdf

[6] Key Comparison CCQM-K96. Determination of Amount Content of Dichromate. Final Report. http://kcdb.bipm.org/appendixB/appbresults/ccqm-k96/ccqm-k96.pdf

[7] Calibration and Measurement Capabilities. Amount of Substance, High Purity Chemicals, Russian Federation. http://kcdb.bipm.org/appendixC/QM/RU/QM_RU_1.pdf

[8] ISO GUIDE 35:2006 Reference Materials—-General and Statistical Principles for Certification. 
Scientific Research Publishing (SCIRP) is one of the largest Open Access journal publishers. It is currently publishing more than 200 open access, online, peer-reviewed journals covering a wide range of academic disciplines. SCIRP serves the worldwide academic communities and contributes to the progress and application of science with its publication.

Other selected journals from SCIRP are listed as below. Submit your manuscript to us via either submit@scirp.org or Online Submission Portal.
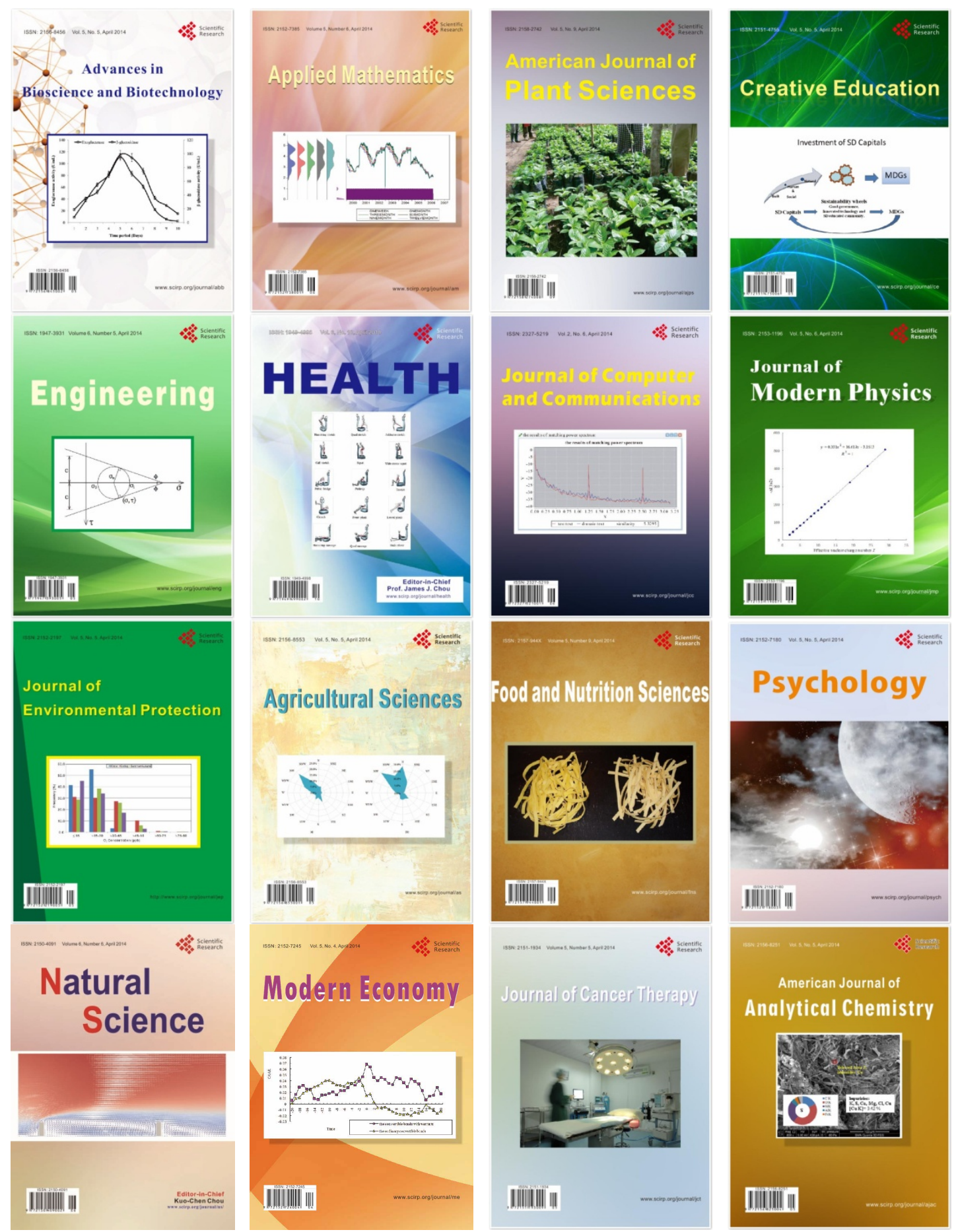